\title{
The Pathway to a High Impact Journal and Scopus Indexation - New Achievement of the International Journal of Cardiovascular Sciences
}

\author{
Claudio Tinoco Mesquita ${ }^{1,2,3}$ (1) \\ Universidade Federal Fluminense, Niterói, RJ - Brazil \\ Nuclear Medicine Department - Hospital Pró-Cardíaco, ${ }^{2}$ Rio de Janeiro, RJ - Brazil \\ Hospital Vitória, ${ }^{3}$ Rio de Janeiro, $R J$ - Brazil
}

"If everyone is moving forward together, then success takes care of itself."

Henry Ford

The International Journal of Cardiovascular Sciences (IJCS) has finally achieved its inclusion in one of the most important abstract and citation databases: Scopus. This international database is sponsored by Elsevier and was launched in 2004. Scopus covers over 25,100 titles (over 23,452 peer-reviewed journals) from approximately 5,000 publishers. IJCS has made some important changes to be accepted in Scopus, including an entirely new and highly interactive website (ijcscardiol.org), a renovation of the editorial board with a more diverse international team of experts in cardiovascular sciences, adoption of open science directives ${ }^{1}$ and gender equity policies, ${ }^{2}$ and a high bar for evaluation of articles for publication. These changes contributed to better results concerning the impact of the journal. From 2017 to 2020, IJCS published 390 articles (191 original articles). IJCS articles were cited 493 times. IJCS's h-index is 13 (Google Scholar), and published articles had 573,736 accesses on SciELO. The rejection rate of IJCS is $46 \%$, and average time for article acceptance is 77 days.

Inclusion in Scopus promotes long-term changes for a scientific journal; there is an increase in internationalization and an improvement in the impact of the articles. Moed et al found that, after a nationally oriented journal is included

\section{Keywords}

Cardiology; Periodicals as Topic/standards; Abstracting and Indexing as Topic/methods; Editorial Policies; Databases, Bibliographic/trends; Citation Databases; Journal Impact Factor. in Scopus, the use of English as publication language and open access status are important determinants of internationalization in the long term. ${ }^{3}$ IJCS has been compliant to these since 2018. Furthermore, the authors showed that national journals from USA, Japan, Brazil, and Iran evaluated after the year they entered Scopus revealed a broadening of the citation impact compared to the overall average. ${ }^{3}$ This is important because IJCS now will be ranked in Scopus in the cardiology and cardiovascular medicine subject category and can be compared with its partners. Elsevier publishes three journal metrics based on the Scopus citation database: (1) the Source-Normalized Impact per Paper (SNIP); (2) the Impact per Publication (IPP); and (3) the SCImago Journal Rank (SJR). SJR is used by the Brazilian Ministry of Education to qualify journals for the evaluation of post-graduate programs. SJR accounts for both the number of citations received by a journal and the importance or prestige of the journals from where such citations come. $^{4}$

Accessing the 2020 SJR rank, we can find 349 journals in the cardiology and cardiovascular medicine subject category, most from North America and Europe. There are 12 journals in this subject from Latin America (Table 1). The best ranked journal from Latin America is Arquivos Brasileiros de Cardiologia (ABC Cardiol), with SJR of 0.400 . Like IJCS, ABC Cardiol is sponsored by the Brazilian Society of Cardiology. IJCS will be soon ranked by SCImago, and authors and reader will be able to use the ranking to evaluate the journal's impact. Our aim is to increase the impact factor of IJCS so that it will be comparable to that of $A B C$ Cardiol, which recently obtained the highest ranking in its history. ${ }^{5}$

Journal rankings and scores are used for a list of academic and economic activities: (1) by academic

Mailing Address: Claudio Tinoco Mesquita

Faculdade de Medicina da Universidade Federal Fluminense Hospital Universitário Antônio Pedro, Setor de Radiologia R. Marquês de Paraná, 303, $2^{\circ}$ andar. Postal Code: 24033-900, Niterói, Rio de Janeiro, RJ - Brazil.

E-mail: claudiotinocomesquita@id.uff.br 
committees to assess performance of competitors, (2) by scientists to choose journals to which they will submit their research findings, (3) for professional promotion inside scientific institutions, and (4) by publishers seeking to promote their journals to attract submissions. ${ }^{4}$ There are many problems with impact factors and journal rankings, and the Leiden Manifesto published in 2015 is a reference for better science evaluation and interactions with society. ${ }^{6}$ Research metrics are important, but the social impact of this research is one of the most crucial aspects that we can measure from a high-quality science evaluation process. Four of the five most visited articles from IJCS are dedicated to the impact of COVID-19 on the cardiovascular system, and the two most visited are devoted to the interactions between COVID and physical activity. ${ }^{7,8}$ IJCS promoted several changes to facilitate COVID-19 papers to be evaluated and published in a timely manner. The social impact of these articles has been clearly demonstrated by the interest created in the scientific community. We hope that the association of good science, social driven impact, and the internationalization related to Scopus indexation will be significant steps toward IJCS becoming a highimpact cardiovascular journal. By evaluating hundreds of articles, sending thousands of emails to reviewers and authors, and issuing hundreds of opinions and a critical analysis of comprehensive cardiovascular scientific production, we have managed to take the IJCS to a new level of international visibility, make it more attractive to high-quality science, and contribute to the transformation of society. This is the objective of a scientific journal: to bring high-quality information and peer-reviewed data that can change the status quo. We still have a long way to go, but we are confident that we will get there by working as a team. Thank you very much to all who contributed for the hard work done. Together we can make a difference in a world that desperately needs solutions for its problems.

Table 1 - SCImago 2020 ranking information from cardiology and cardiovascular medicine journals

\begin{tabular}{|c|c|c|c|c|c|}
\hline Title & SJR & Quartile & H-index & Country & Publisher \\
\hline $\begin{array}{l}\text { Arquivos Brasileiros de } \\
\text { Cardiologia }\end{array}$ & 0.400 & Q3 & 53 & Brazil & $\begin{array}{l}\text { Sociedade Brasileira de } \\
\text { Cardiologia }\end{array}$ \\
\hline $\begin{array}{l}\text { Brazilian Journal of } \\
\text { Cardiovascular Surgery }\end{array}$ & 0.324 & Q3 & 26 & Brazil & $\begin{array}{l}\text { Sociedade Brasileira de Cirurgia } \\
\text { Cardiovascular }\end{array}$ \\
\hline Jornal Vascular Brasileiro & 0.224 & Q3 & 15 & Brazil & $\begin{array}{c}\text { Sociedade Brasileira de } \\
\text { Angiologia e Cirurgia Vascular }\end{array}$ \\
\hline $\begin{array}{l}\text { Revista Latinoamericana de } \\
\text { Hipertension }\end{array}$ & 0.210 & Q3 & 7 & Venezuela & $\begin{array}{c}\text { Sociedad Latinoamericana de } \\
\text { Hipertension }\end{array}$ \\
\hline Revista Argentina de Cardiologia & 0.155 & Q4 & 11 & Argentina & $\begin{array}{c}\text { Sociedad Argentina De } \\
\text { Cardiologia }\end{array}$ \\
\hline $\begin{array}{l}\text { Archivos de Cardiologia de } \\
\text { Mexico }\end{array}$ & 0.149 & Q4 & 17 & Mexico & $\begin{array}{c}\text { Instituto Nacional de Cardiologia } \\
\text { Ignazio Chavez }\end{array}$ \\
\hline $\begin{array}{l}\text { Revista Colombiana de } \\
\text { Cardiologia }\end{array}$ & 0.125 & Q4 & 10 & Colombia & $\begin{array}{l}\text { Sociedad Colombiana } \\
\text { de Cardiologia y Cirugia } \\
\text { Cardiovascular }\end{array}$ \\
\hline $\begin{array}{l}\text { Revista de la Federacion } \\
\text { Argentina de Cardiologia }\end{array}$ & 0.112 & Q4 & 5 & Argentina & $\begin{array}{l}\text { Federacion Argentina de } \\
\text { Cardiologia }\end{array}$ \\
\hline Revista Mexicana de Cardiologia & 0.108 & Q4 & 5 & Mexico & $\begin{array}{l}\text { Asociacion Nacional de } \\
\text { Cardiologos de Mexico }\end{array}$ \\
\hline $\begin{array}{l}\text { Revista Mexicana de Enfermeria } \\
\text { Cardiologica }\end{array}$ & 0.105 & Q4 & 2 & Mexico & $\begin{array}{l}\text { Sociedad Mexicana de } \\
\text { Cardiologia }\end{array}$ \\
\hline Insuficiencia Cardiaca & 0.101 & Q4 & 5 & Argentina & Silver Horse S.R.L. \\
\hline Revista Mexicana de Angiologia & 0.101 & Q4 & 3 & México & Sociedad Mexicana De Angiologia \\
\hline
\end{tabular}




\section{References}

1. Mesquita C T, Borim D, Rochitte C E. Open Science, Cardiology and 20 years of SciELO (Scientific Electronic Library Online). Int J Cardiovasc Sci.2019;32(3):203-4. doi:10.5935/2359-4802.20190036.

2. Mesquita C T, Lacerda A G. Sex and Gender Equity in Research and Publishing: International Journal of Cardiovascular Sciences endorses SAGER Guidelines. Int J cardiovasc Sci.2021;34(6):597-8. DOI:10.36660/ ijcs.20210221

3. Moed HF. Moya-Anegon F, Guerrero-BoteV, Lopez-Illescas c. Are nationally oriented journals indexed in Scopus becoming more international? The effect of publication language and access modality. J Inform.2020;14(2). Doi:10.1016/j.joi.2020.101011

4. Bradshaw CJA,Brook BW, How PLoS One.2016;11(3):e0149852 doi: 10.1371/journal.pone.0149852
5. Rochitte, C. E. Impact factor of 2.0, a new historical record for abc cardiol - many thanks to our cardiology and scientific community. Arq Bras Cardiol.2021; 111(1):266-9. Doi: 10.5935/abc.20180129

6. Hicks D, Wouters P, Waltman L, de Rijcke S, Rafols I. The Leiden Manifesto for research metrics. Nature.2015;520(7548):429-31. Doi: $10.1038 / 520429$ a

7. Silva FB, Fonseca B, Domecq F, Facio MR, Prado C, Toledo L, Tuche W. Athletes Health during Pandemic Times: Hospitalization Rates and Variables Related to COVID-19 Prevalence among Endurance Athletes. Int J cardiovasc Sci. 2021;34(3):274-83. doi:10.36660/ijcs.20200208.

8. Araújo SGS. Physical Activity, Exercise and Sports and Covid-19: What Really Matters. Int J Cardiovasc Sci. 2021;34(2):113-5. doi:10.36660/ ijcs.20210003. 